Prepared in cooperation with the U.S. Department of the Army

\title{
Hydrogeologic Characteristics and Water Quality of a Confined Sand Unit in the Surficial Aquifer System, Hunter Army Airfield, Chatham County, Georgia
}

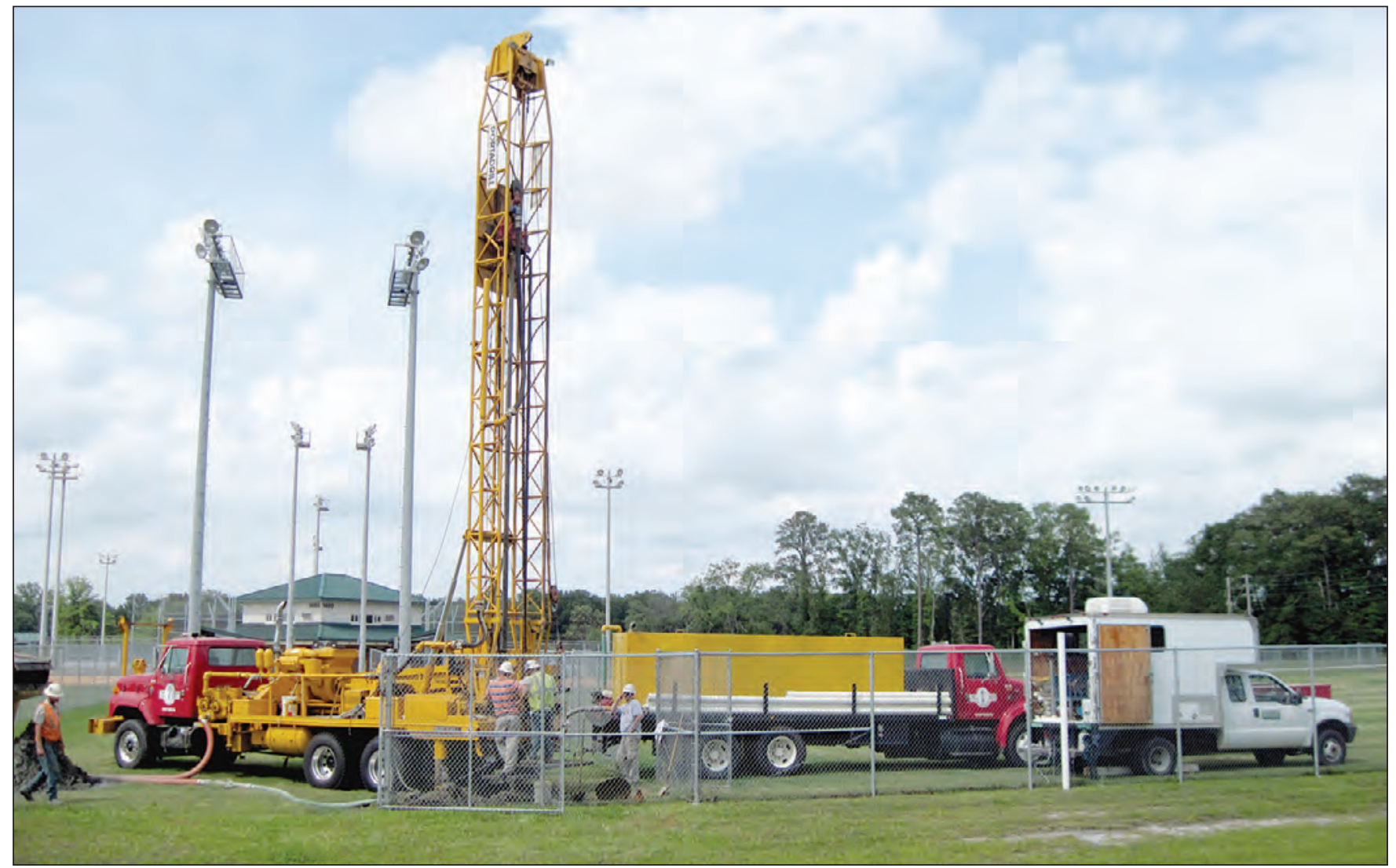

Scientific Investigations Report 2012-5082 
Cover. Drilling the irrigation well 360397 at Hunter Army Airfield ballfields, May 2, 2012. Photo by Michael D. Hamrick, USGS. 


\section{Hydrogeologic Characteristics and Water Quality of a Confined Sand Unit in the Surficial Aquifer System, Hunter Army Airfield, Chatham County, Georgia}

By Gerard J. Gonthier

Prepared in cooperation with the U.S. Department of the Army

Scientific Investigations Report 2012-5082 


\title{
U.S. Department of the Interior \\ KEN SALAZAR, Secretary \\ U.S. Geological Survey \\ Marcia K. McNutt, Director
}

\section{U.S. Geological Survey, Reston, Virginia: 2012}

\begin{abstract}
For more information on the USGS — the Federal source for science about the Earth, its natural and living resources, natural hazards, and the environment, visit http://Www.usgs.gov or call 1-888-ASK-USGS

For an overview of USGS information products, including maps, imagery, and publications, visit $h$ ttp://www.usgs.gov/pubprod

To order this and other USGS information products, visit http://store.usgs.gov
\end{abstract}

Any use of trade, product, or firm names is for descriptive purposes only and does not imply endorsement by the U.S. Government.

Although this report is in the public domain, permission must be secured from the individual copyright owners to reproduce any copyrighted materials contained within this report.

Suggested citation:

Gonthier, G.J., 2012, Hydrogeologic characteristics and water quality of a confined sand unit in the surficial aquifer system, Hunter Army Airfield, Chatham County, Georgia: U.S. Geological Survey Scientific Investigations Report 2012-5082, 14 p., available online at http://pubs.usgs.gov/sir/2012/5082/. 


\section{Contents}

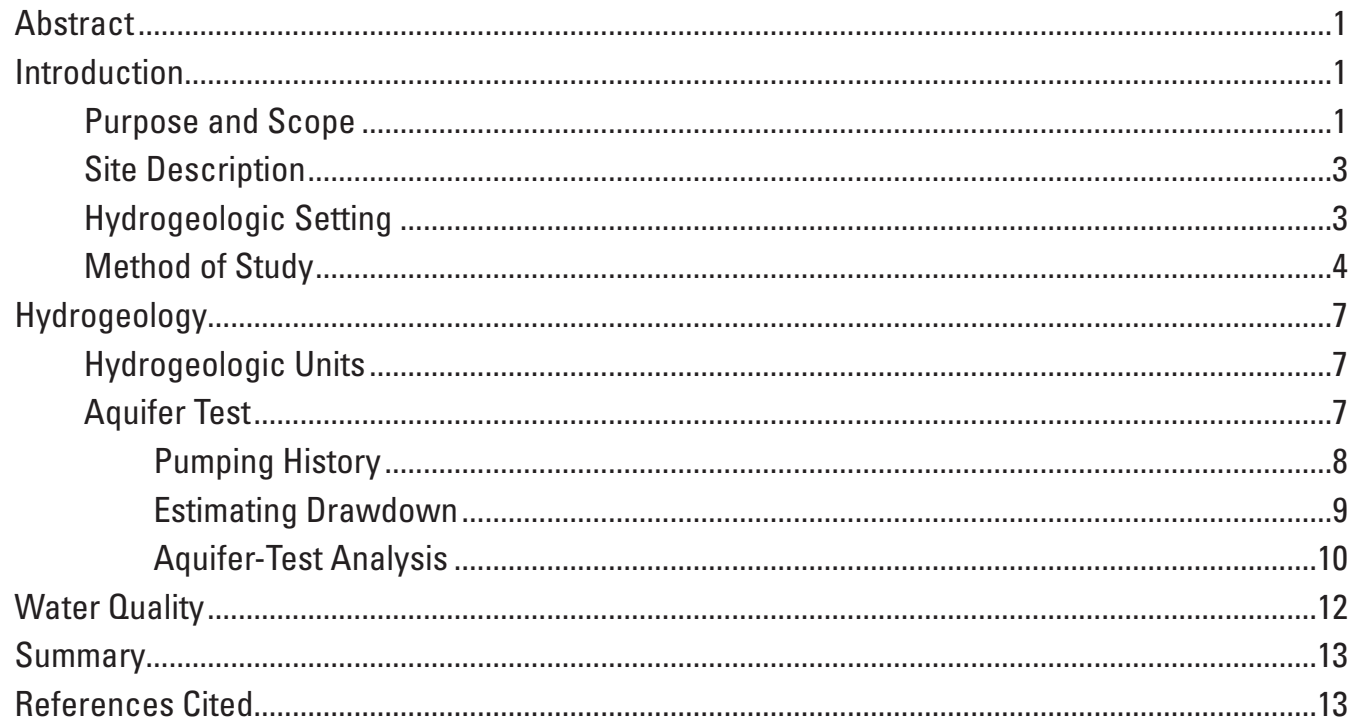

\section{Figures}

1. Maps showing location of well 360397 at Hunter Army Airfield and

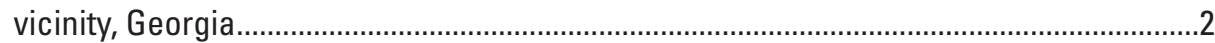

2. Generalized correlation of geologic and hydrogeologic units in the Coastal Plain of Georgia

3. Log graphs showing lithology and geophysical properties of ballfield well 360397 at Hunter Army Airfield near Savannah, Georgia .

4. Well construction diagram of ballfield well 360397 at Hunter Army Airfield near Savannah, Georgia

5. Graphs showing water level in, and discharge from, ballfield well 360397 at Hunter Army Airfield near Savannah, Georgia, July 11-14, 2011, general water level, vertical close-up of water level near static level, and discharge rate ...................8

6. Graphs showing estimated background and measured water level in ballfield well 360397 at Hunter Army Airfield near Savannah, Georgia, June 30-July 18, 2011, general water level and vertical close-up of graph $A$ near the estimated background water level.

7. Graph showing simulated and measured drawdown and residual drawdown at ballfield well 360397 at Hunter Army Airfield near Savannah, Georgia, in response to three pumping events, July 11-14, 2011

\section{Tables}

1. Discharge-rate changes used in the model to simulate the drawdown in well 360397 at Hunter Army Airfield near Savannah, Georgia, July 2011

2. Water quality in well 360397 , ballfield complex, Hunter Army Airfield near Savannah, Georgia, July 14, 2011. 


\section{Conversion Factors and Datums}

\begin{tabular}{lcl}
\hline \multicolumn{1}{c}{ Multiply } & By & \multicolumn{1}{c}{ To obtain } \\
\hline inch & Length & \\
inch & 2.54 & centimeter $(\mathrm{cm})$ \\
foot $(\mathrm{ft})$ & 25.4 & millimeter $(\mathrm{mm})$ \\
\hline & 0.3048 & meter $(\mathrm{m})$ \\
\hline foot per day $(\mathrm{ft} / \mathrm{d})$ & Flow rate & meter per day $(\mathrm{m} / \mathrm{d})$ \\
gallon per minute $(\mathrm{gal} / \mathrm{min})$ & 0.3048 & liter per second $(\mathrm{L} / \mathrm{s})$ \\
inch per month (in/mo) & 0.06309 & meter per month $(\mathrm{m} / \mathrm{mo})$ \\
inch per year $(\mathrm{in} / \mathrm{yr})$ & 0.0254 & millimeter per year $(\mathrm{mm} / \mathrm{yr})$ \\
\hline & 25.4 & meter per day $(\mathrm{m} / \mathrm{d})$ \\
\hline foot per day $(\mathrm{ft} / \mathrm{d})$ & Hydraulic conductivity & meter squared $\mathrm{per}$ day $(\mathrm{m} / \mathrm{d})$ \\
\hline
\end{tabular}

Temperature in degrees Celsius $\left({ }^{\circ} \mathrm{C}\right)$ may be converted to degrees Fahrenheit $\left({ }^{\circ} \mathrm{F}\right)$ as follows:

$$
{ }^{\circ} \mathrm{F}=\left(1.8 \times{ }^{\circ} \mathrm{C}\right)+32
$$

Vertical coordinate information is referenced to the North American Vertical Datum of 1988 (NAVD 88).

Altitude, as used in this report, refers to distance above the vertical datum.

* The standard unit for transmissivity is cubic foot per day per square foot times foot of aquifer thickness $\left[\left(\mathrm{ft}^{3} / \mathrm{d}\right) / \mathrm{ft}^{2}\right] \mathrm{ft}$. In this report, the mathematically reduced form, foot squared per day $\left(\mathrm{ft}^{2} / \mathrm{d}\right)$, is used for convenience.

Specific conductance is given in microsiemens per centimeter at 25 degrees Celsius $(\mu \mathrm{S} / \mathrm{cm}$ at $\left.25^{\circ} \mathrm{C}\right)$.

Concentrations of chemical constituents in water are given either in milligrams per liter ( $\mathrm{mg} / \mathrm{L}$ ) or micrograms per liter $(\mu \mathrm{g} / \mathrm{L})$. 


\section{Acknowledgments}

The author appreciates the assistance of the U.S. Army and Oak Ridge National Laboratory for providing onsite support and data. Special thanks go to Stanley Thomas, C. Brent Rabon, Eric Stulpin, Tressa Rutland, and Nathaniel Williams II, of the U.S. Army Environmental Protection and Compliance Branch, and to Gina Jones of SpecPro Environmental Services, L.L.C. Sam Martin Drilling drilled the test hole and completed the well. Water samples were analyzed by Test America, Inc., Savannah, Georgia.

Aquifer-test design and collection of well discharge, water-level, and water-quality data were performed by 0. Gary Holloway of the U.S. Geological Survey. Interpretation of drill cuttings and logging activities were performed with the assistance of Michael D. Hamrick of the U.S. Geological Survey. 



\title{
Hydrogeologic Characteristics and Water Quality of a Confined Sand Unit in the Surficial Aquifer System, Hunter Army Airfield, Chatham County, Georgia
}

\author{
By Gerard J. Gonthier
}

\section{Abstract}

An 80-foot-deep well (36Q397, U.S. Geological Survey site identification 320146081073701) was constructed at Hunter Army Airfield to assess the potential of using the surficial aquifer system as a water source to irrigate a ballfield complex. A 300-foot-deep test hole was drilled beneath the ballfield complex to characterize the lithology and water-bearing characteristics of sediments above the Upper Floridan aquifer. The test hole was then completed as well 36Q397 open to a 19-foot-thick shallow, confined sand unit contained within the surficial aquifer system. A single-well, 24-hour aquifer test was performed by pumping well 36Q397 at a rate of 50 gallons per minute during July $13-14,2011$, to characterize the hydrologic properties of the shallow, confined sand unit. Two pumping events prior to the aquifer test affected water levels. Drawdown during all three pumping events and residual drawdown during recovery periods were simulated using the Theis formula on multiple changes in discharge rate. Simulated drawdown and residual drawdown match well with measured drawdown and residual drawdown using values of horizontal hydraulic conductivity and specific storage, which are typical for a confined sand aquifer. Based on the hydrologic parameters used to match simulated drawdown and residual drawdown to measured drawdown and residual drawdown, the transmissivity of the sand was determined to be about 400 feet squared per day. The horizontal hydraulic conductivity of the sand was determined to be about 20 feet per day. Analysis of a water-quality sample indicated that the water is suitable for irrigation. Sample analysis indicated a calcium-carbonate type water having a total dissolved solids concentration of 39 milligrams per liter. Specific conductance and concentrations of all analyzed constituents were below those that would be a concern for irrigation, and were below primary and secondary waterquality criteria levels.

\section{Introduction}

Concern over saltwater intrusion at Hilton Head Island, South Carolina, has resulted in increased restrictions on groundwater withdrawal from the Upper Floridan aquifer by the Georgia Environmental Protection Division (GaEPD). Restrictions applied to a 24-county coastal area of Georgia include Hunter Army Airfield near the city of Savannah (fig. 1). To meet growing water demand in the 24-county coastal area of Georgia, GaEPD has encouraged usage of alternative sources of water to the Upper Floridan aquifer, including wells completed in the surficial aquifer system. Hunter Army Airfield seeks to use the surficial aquifer system to irrigate a ballfield complex. To assess the water-supply potential of the surficial aquifer system to irrigate this complex, the U.S. Geological Survey (USGS), in cooperation with the U.S. Department of the Army (U.S. Army), conducted an investigation during July 2011 to determine the hydrogeology and water quality of the surficial aquifer system. The data collected from this and other similar studies will be used to develop a more thorough understanding of potential use of the surficial aquifer system in the region.

\section{Purpose and Scope}

This report describes the hydrogeology and water quality of a shallow, confined sand unit contained in the surficial aquifer system beneath a ballfield complex at Hunter Army Airfield, and presents the hydrologic characteristics of this sand unit based on the results of an aquifer test performed during July 2011. The hydrogeology of the shallow, confined sand unit is characterized along with descriptions of borehole geophysical data and geologic interpretation of well cuttings that define the shallow, confined sand unit's lithology and thickness. Transmissivity of the shallow, confined sand unit 

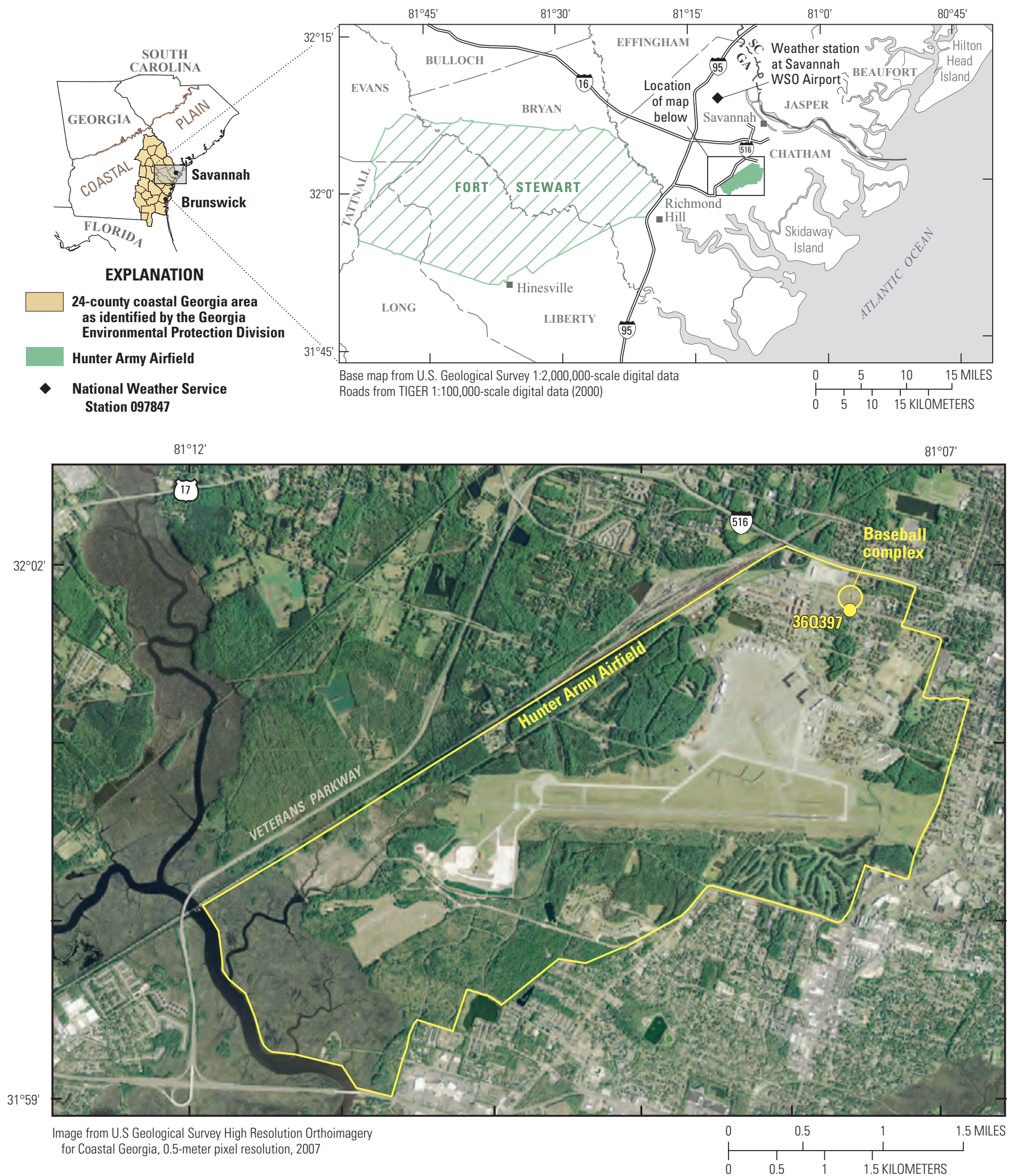

Figure 1. Location of well 360397 at Hunter Army Airfield and vicinity, Georgia. 
was estimated using data from a prospective new irrigation well (36Q397) that was pumped for 24 hours at a discharge rate of 50 gallons per minute (gal $/ \mathrm{min})$. A groundwater sample was collected from the pump discharge during the last hour of the aquifer test. The sample was analyzed for $\mathrm{pH}$, total alkalinity, specific conductance, total dissolved solids, and major ions.

\section{Site Description}

The U.S. Army Fort Stewart and Hunter Army Airfield, Georgia, are home to the 3rd Infantry Division. The Hunter Army Airfield is the focus of this investigation and is located in the Coastal Plain in central Chatham County near Savannah, Ga. (fig. 1). The site is characterized by flat topography, with sandy topsoil typical of the coastal area of Georgia. Land surface altitude is about 24 feet (ft). Well 36Q397 is located at the southern edge of a ballfield complex.

The study area has a mild climate with warm, humid summers and mild winters. Long-term climatic patterns in the area are derived from records provided by the National Weather Service Station at Savannah International Airport (climatological station "Savannah WSO Airport, Ga. [097847]," accessed on Sept. 27, 2011, at http://www.sercc.com/cgi-bin/ sercc/cliMAIN.pl?ga7847). During 1971-2000, precipitation at station 097847 averaged about 49 inches per year (in/yr). Maximum monthly rainfall (exceeding 4 inches per month [in/mo]) generally occurs during June-September, with monthly rainfall totals averaging less than 4 inches during the rest of the year. Mean monthly pan evaporation at station 097847 during 1965-2003 ranged from 2.43 to $8.49 \mathrm{in} / \mathrm{mo}$, with maximum rates from April to August (Clarke and others, 2010).

\section{Hydrogeologic Setting}

Chatham County and Hunter Army Airfield are underlain by Coastal Plain strata consisting of consolidated to unconsolidated layers of sand and clay and semiconsolidated to very dense layers of limestone and dolostone (Clarke and others, 1990). These sediments constitute the following three major aquifer systems, in order of increasing depth: the surficial aquifer system, Brunswick aquifer system, and Floridan aquifer system. In the coastal area, the surficial aquifer system (fig. 2) consists of Miocene-to-Holocene interlayered sand, clay, and thin limestone beds (Clarke, 2003). At Skidaway Island (fig. 1) in Chatham County, the surficial aquifer system consists of an upper unconfined sand zone and lower semiconfined sand zone separated by a clay semiconfining layer (Clarke and others, 1990). At Hunter Army Airfield, the surficial aquifer system consists of fine sand at depths of less than $100 \mathrm{ft}$ that overlie silty clay and dense phosphatic limestone of the Brunswick aquifer system.

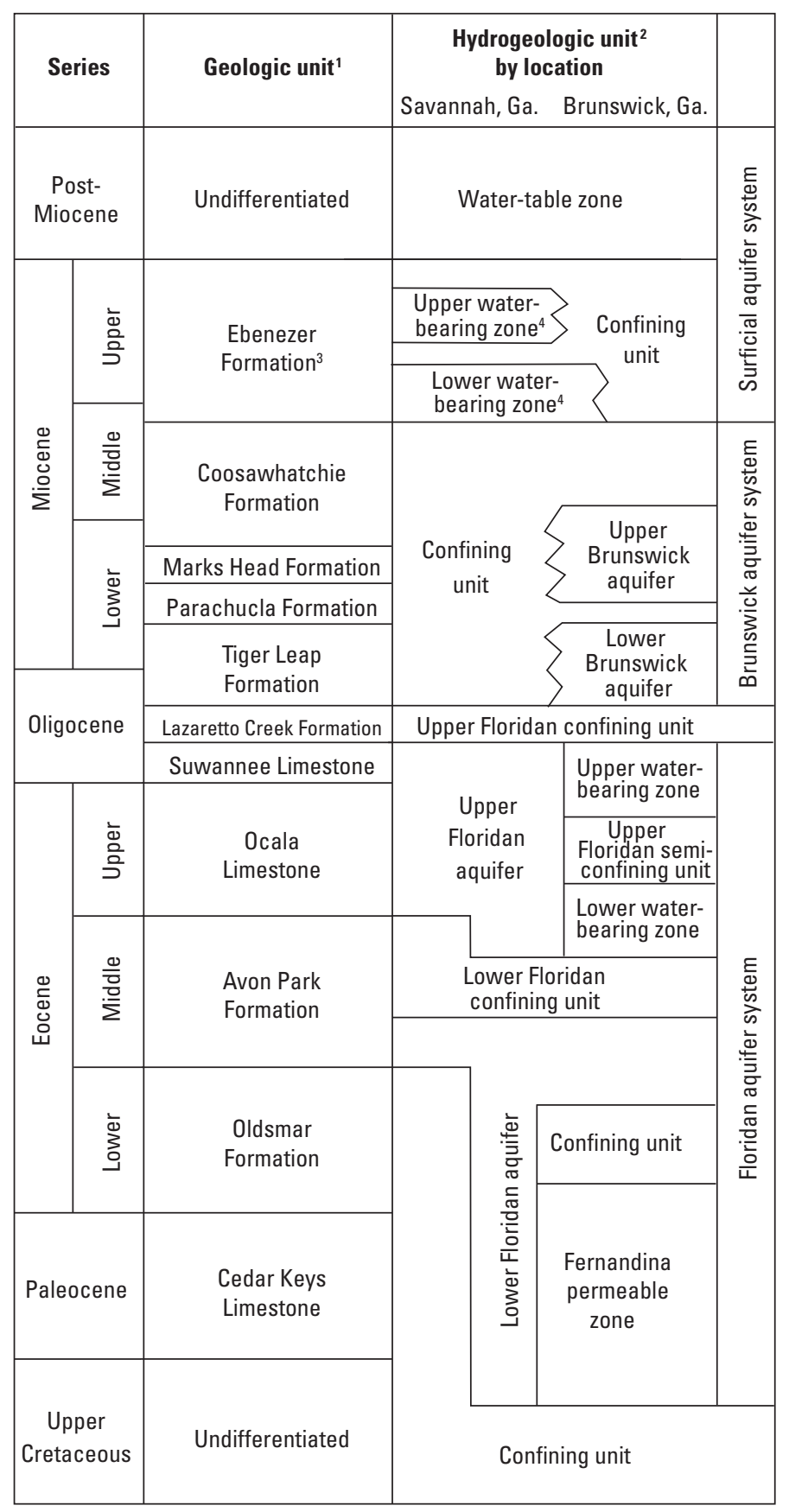

'Modified from Randolph and others, 1991; Weems and Edwards, 2001. ${ }^{2}$ Modified from Randolph and others, 1991; Clarke and Krause, 2000.

${ }^{3}$ Huddleston (1988) has the Ebenezer Member as part of the Coosawhatchie Formation. ${ }^{4}$ These terms are specific to work on Skidaway Island.

Figure 2. Generalized correlation of geologic and hydrogeologic units in the Coastal Plain of Georgia. 


\section{Hydrogeologic Characteristics and Water Quality of a Confined Sand Unit in the Surficial Aquifer System, Hunter Army Airfield}

Within the Hunter Army Airfield and near Savannah, the Brunswick aquifer system is of low permeability with no discernible water-bearing units (fig. 2). The Brunswick aquifer system consists of silty clay and dense phosphatic limestone (Clarke, 2003), and is roughly $200 \mathrm{ft}$ thick (Clarke and others, 2011). The Brunswick aquifer system overlies limestone of the Floridan aquifer system.

The Floridan aquifer system is the most productive of the three aquifer systems. It consists of carbonate rocks of varying permeability that are separated into several water-bearing zones by layers of relatively dense limestone that act as minor localized semiconfining units. The thickness of the Floridan aquifer system, within the Hunter Army Airfield vicinity near Savannah, is close to $750 \mathrm{ft}$ (Miller, 1986).

\section{Method of Study}

A 300-ft-deep test hole was drilled using a 9-7/8-inch rotary drill to characterize the water-bearing characteristics of sediments above the Upper Floridan aquifer (fig. 3). Cuttings were collected every $10 \mathrm{ft}$ or as lithologic changes were observed. Borehole geophysical logging was performed to characterize physical properties of the penetrated sediments and interstitial fluid: natural gamma, spontaneous potential, and lateral, long-normal (64-inch), and short-normal (16-inch) resistivity. The bottom $220 \mathrm{ft}$ of the test hole was filled with bentonite grout to create a hydraulic barrier between the surficial aquifer system and the underlying Brunswick aquifer system. A well was installed to a depth of about $80 \mathrm{ft}$ using schedule 40, 8-inch-diameter polyvinyl chloride casing and slotted screen (figs. 3 and 4). A gravel pack was placed around the screen and bentonite grout was used to seal the well above the gravel pack to land surface.

Continuous and intermittent groundwater-level measurements were made at the pumped well before, during, and after the aquifer test, in accordance with USGS standard procedures (Stallman, 1971; Cunningham and Schalk, 2011). Manual, intermittent water-level measurements in wells were made for calibration of groundwater-level recorder readings and for direct monitoring of the aquifer test. Manual measurements were made using an electric tape to the nearest $0.01 \mathrm{ft}$ following procedures described in Garber and Koopman (1968) and Cunningham and Schalk (2011). Continuous groundwater-level recorders were equipped with submerged, vented pressure transducers. For long-term monitoring before and after the aquifer test, pressure transducers recorded water-level measurements every 15 minutes; for the aquifer test, pressure transducers recorded water-level measurements every 5 seconds or every minute.

Well discharge was measured as cumulative volume of water pumped using a digital-impeller flow meter. Data were recorded every minute and were used to determine the average discharge rate for each minute of data collection.

Transmissivity of the shallow, confined sand unit was estimated by simulating drawdown during three pumping events and residual drawdown during the recovery periods after the pumping events. The last of the three pumping events was the aquifer test. The simulation was performed with the spreadsheet function SUMTheis (Keith J. Halford, U.S. Geological Survey, written commun., June 1, 2010; an update to software published in Halford, 2006), which uses the Theis formula (Theis, 1935). Drawdown and residual drawdown in well 36Q397 were calculated as the estimated background water level - that is, the water level in the absence of pumping - minus the water level measured during the test period. Values of transmissivity and storativity were adjusted in the SUMTheis spreadsheet function until simulated values matched measured drawdown and residual drawdown. The transmissivity value that yielded an acceptable match of simulated to measured drawdown and residual drawdown was considered to be the estimate of transmissivity associated with the shallow, confined sand unit.

A water sample was collected from well 36Q397, 23 hours into the 24-hour aquifer test. By this time, groundwater-flow conditions were stable and more than three well-casing volumes of water had been removed. Whole water was collected at the discharge outflow. The sampled water was analyzed for $\mathrm{pH}$; total alkalinity; total dissolved solids; cations of calcium, iron, magnesium, manganese, potassium, and sodium; and anions of bromide, chloride, fluoride, and sulfate. 


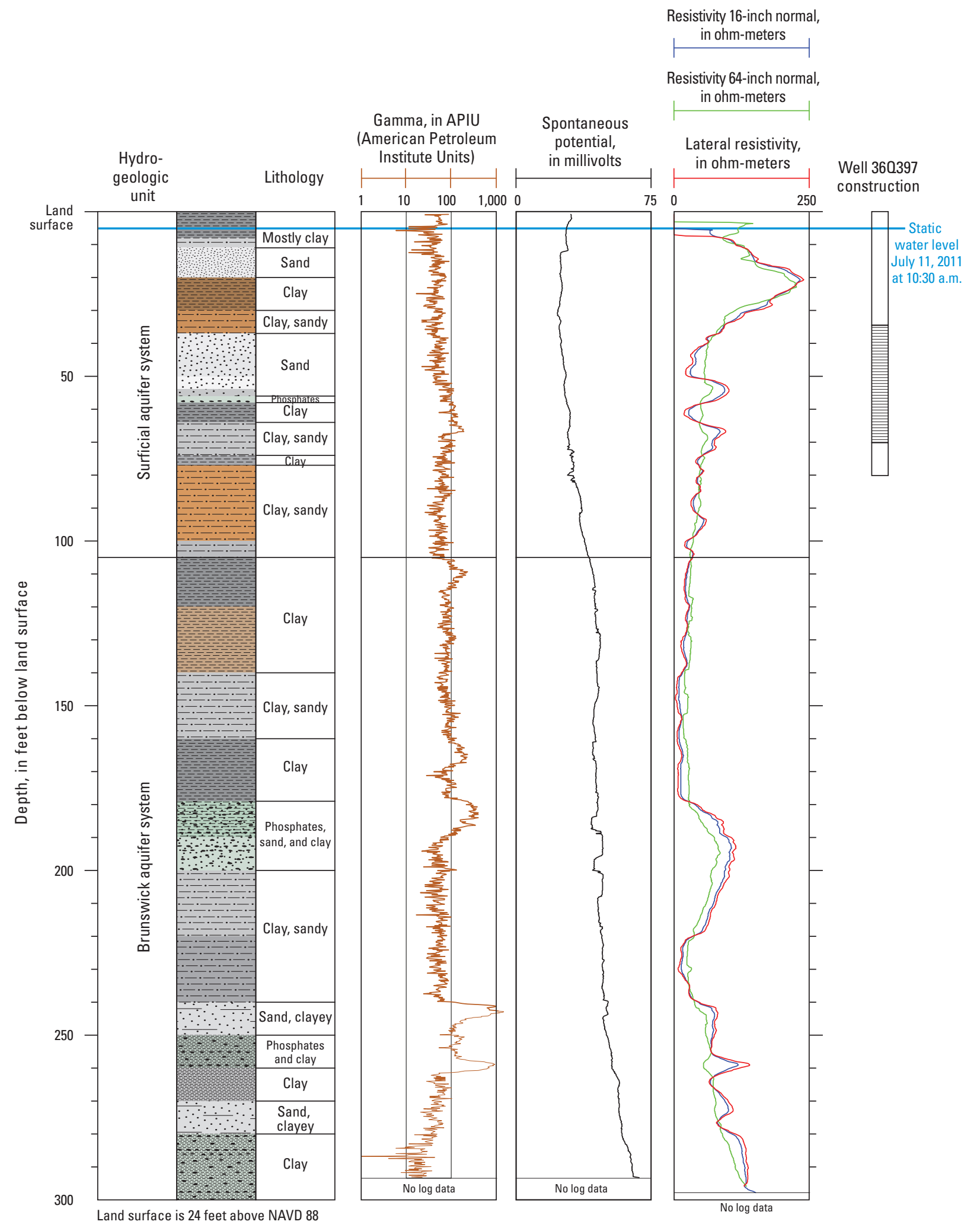

Figure 3. Lithology and geophysical properties of ballfield well 360397 at Hunter Army Airfield near Savannah, Georgia. 


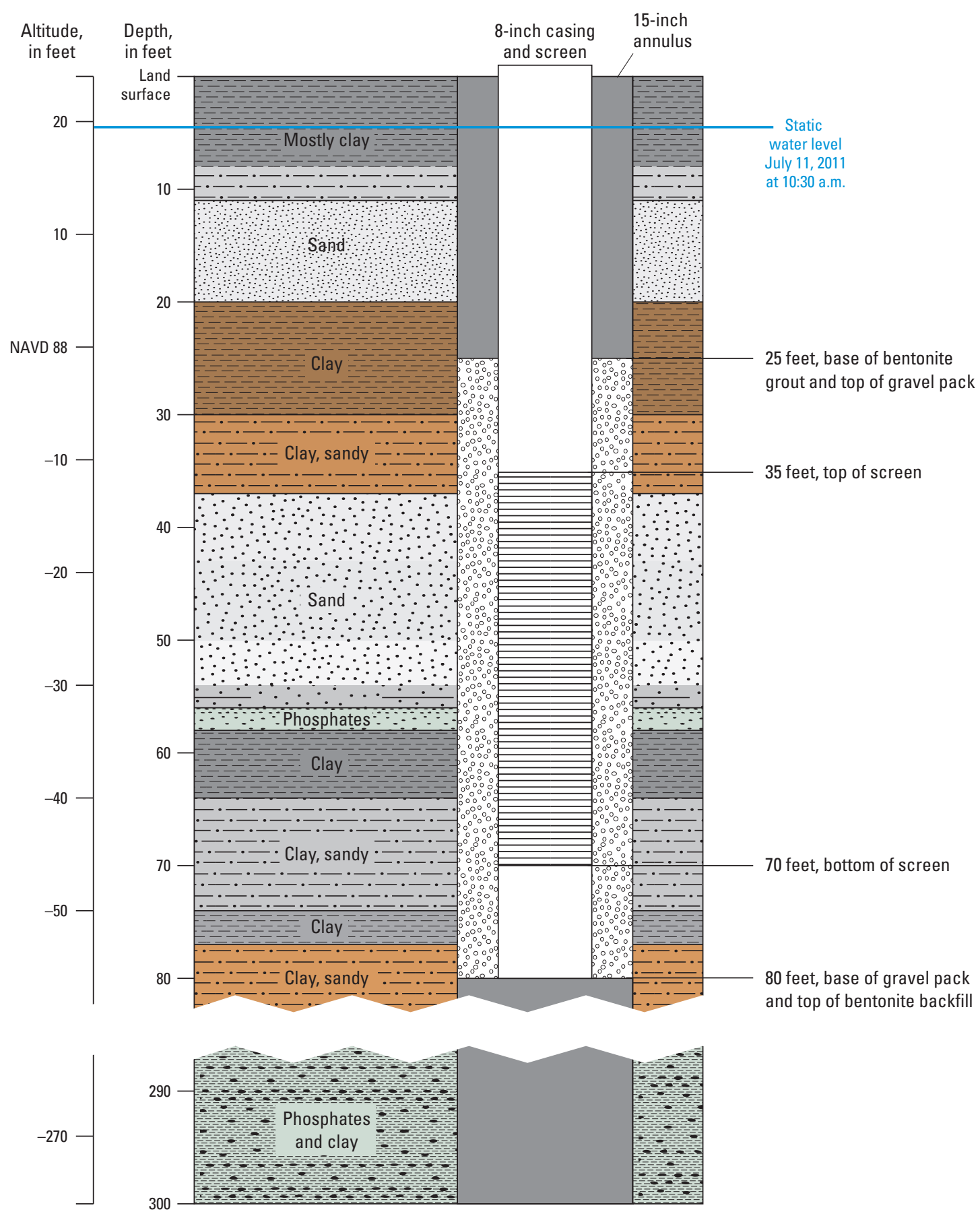

Figure 4. Well construction diagram of ballfield well 360397 at Hunter Army Airfield near Savannah, Georgia. 


\section{Hydrogeology}

To assess the hydrogeology and water quality of the surficial aquifer system at Hunter Army Airfield, detailed site investigations occurred during 2011 at the south end of the ballfield complex (fig. 1). This investigation included completion of a test boring to a depth of $300 \mathrm{ft}$, collection of drillers' and geophysical logs, construction of a new well (36Q397) completed with a screen from 35 to $70 \mathrm{ft}$ deep (figs. 3 and 4), a 24-hour constant-discharge aquifer test, and collection and analysis of a water-quality sample.

\section{Hydrogeologic Units}

Drillers' and geophysical logs indicate a sediment sequence consisting of mostly fine sand and clay within the 300-ft depth of the test hole (fig. 3). Comparison of the drillers' log and geophysical logs at well 36Q397 with previous work by Clarke and others (1990) and Weems and Edwards (2001) indicate that the 300-ft-deep test hole penetrated the surficial aquifer system and most of the Brunswick aquifer system. The absence of carbonates in drillers' and geophysical logs indicates that the top of the Upper Floridan aquifer lies at an undetermined depth below the bottom of the test hole.

In the test hole at the Hunter Army Airfield ballfieldcomplex site, the surficial aquifer system is interpreted to extend from land surface to about $105 \mathrm{ft}$ below land surface (fig. 3). Two shallow sand layers were detected within the surficial aquifer system - an upper sand layer extending from 11 to $20 \mathrm{ft}$ below land surface, and a lower sand layer extending from 37 to $56 \mathrm{ft}$ below land surface. The upper sand layer consists of light gray fine sand and is similar to the water-table zone of the surficial aquifer system described by Clarke (2003), although the presence of about $10 \mathrm{ft}$ of overlying clay with some sand indicates the potential for confinement. The lower sand layer consists of mostly coarse gray sand with some fine sand and is similar to one of the two confined zones described by Clarke (2003). The well screen and gravel pack for well 36Q397 is open to the lower (confined) sand unit and some clay layers above and below the confined sand unit (fig. 4). This lower sand layer within the surficial aquifer system is termed the shallow, confined sand unit that is the tested aquifer in this report.

The Brunswick aquifer system was encountered from a depth of $105 \mathrm{ft}$ to the 300 -ft total depth of the test hole. In the test hole, the Brunswick aquifer system consists of low permeability layers of clay and fine sand with little water-bearing potential. Relatively sandy layers were detected at depths below land surface of 240-250 ft and 270-280 ft. Phosphaterich layers associated with high natural-gamma emissions and high resistivity were encountered at depths below land surface of 179-200 ft, and 250-260 ft (fig. 3).

\section{Aquifer Test}

A single-well aquifer test was conducted at Hunter Army Airfield to estimate the transmissivity of the shallow, confined sand unit within the surficial aquifer system. A 24-hour aquifer test was performed by pumping well 36Q397 at a rate of $50 \mathrm{gal} / \mathrm{min}$ from 2:00 p.m., July 13th, until 2:00 p.m., July 14th. The water level in the well dropped from about $5 \mathrm{ft}$ below land surface just prior to the aquifer test to about $30 \mathrm{ft}$ in response to aquifer test pumping, remaining above the top of the shallow, confined sand unit during the aquifer test. 


\section{Hydrogeologic Characteristics and Water Quality of a Confined Sand Unit in the Surficial Aquifer System, Hunter Army Airfield}

\section{Pumping History}

Two pumping events prior to the aquifer test resulted in residual drawdown and measurable water-level recovery during the aquifer test (fig. 5). The first pumping event occurred on July 11, 2011, 2 days prior to the aquifer test, when well 36Q397 was developed for 6 hours. Discharge and water-level data were unavailable during this 6-hour period; however, discharge most probably was intermittent in order to develop the well.
A second pumping event occurred during an attempt to start the aquifer test at 11:01 a.m. on July 13, 2011; however, the 100-plus-gal $/ \mathrm{min}$ pumping rate caused excessive drawdown over a short period of time, and the aquifer test was aborted after 11 minutes and 40 seconds. About 3 hours after this second pumping event began (2:00 p.m.), the water level continued to recover but was lower than the water level just prior to this aborted attempt (fig. 5). The aquifer test was started a second time at 2:00 p.m. on July 13 with a lower pumping rate of $50 \mathrm{gal} / \mathrm{min}$, regardless of the residual drawdown and ongoing water-level recovery that existed in the pumped well resulting from the failed first attempt to start the test.
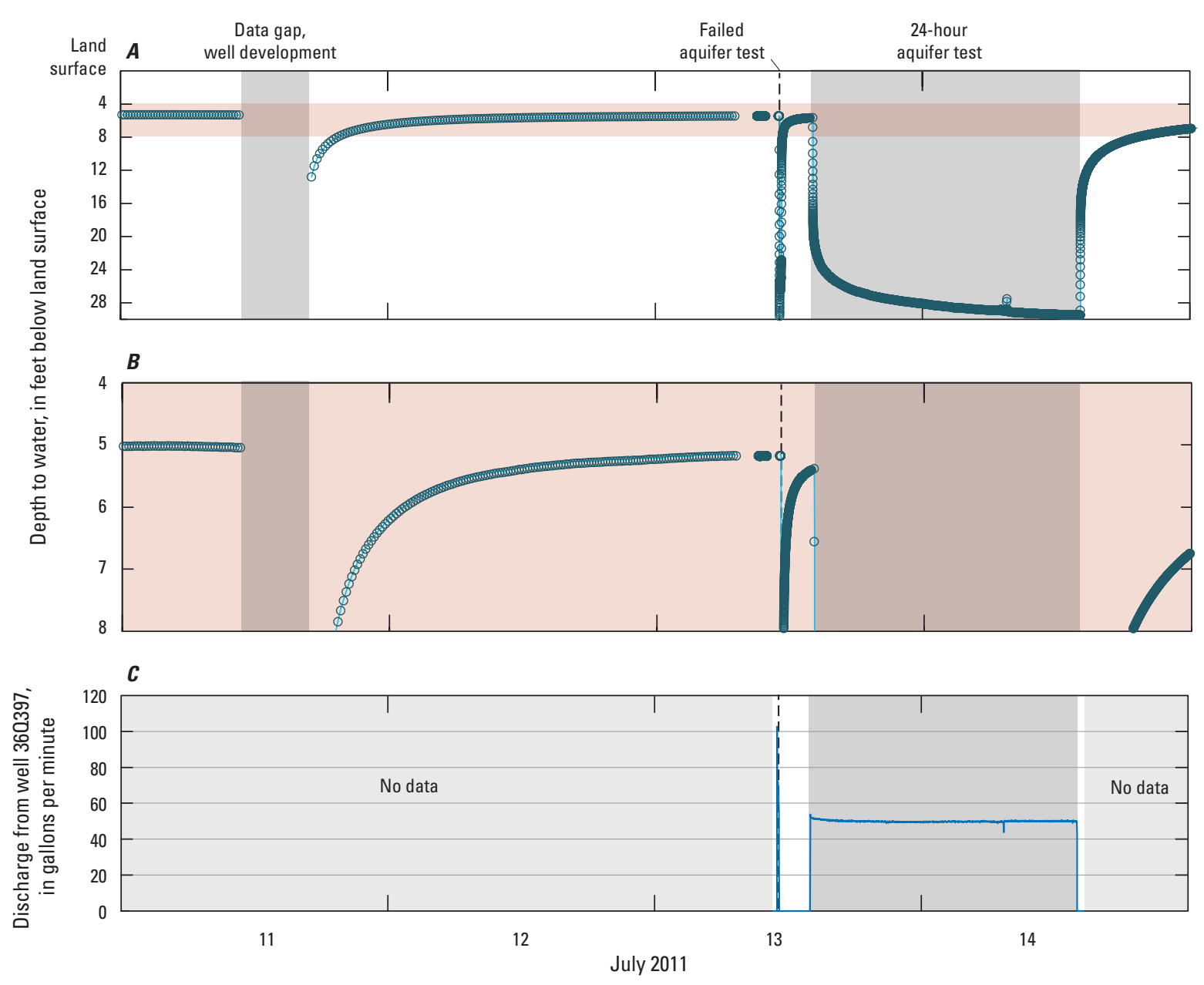

Figure 5. Water level in, and discharge from, ballfield well 360397 at Hunter Army Airfield near Savannah, Georgia, July 11-14, 2011. A. General water level. B. Vertical close-up of water level near static level. $C$. Discharge rate. 


\section{Estimating Drawdown}

Water-level trends caused by multiple pumping events and natural, long-term water-level changes required filtering of water levels measured during the aquifer test to estimate and identify test-related drawdown and residual drawdown (Halford, 2006). Drawdown, as described here, is in response to multiple pumping events: well development on July 11, 2011; the failed aquifer test on July 13 at 11:01 a.m.; and the successful aquifer test on July 13 at 2:00 p.m. Estimated drawdown was calculated using estimates of background water level subtracted from water levels measured during the test. The background water level was the water level that would have occurred during the test period in the absence of pumping events. An initial estimate of background water level was made by extrapolating a simple trend of measured water level prior to pumping into the period of the pumping events. From June 30th until the start of well development on July 11, water levels declined in a near-linear manner (fig. 6). Superimposed on this near-linear water-level decline are minor daily fluctuations with an amplitude of about $0.02 \mathrm{ft}$. These daily fluctuations were negligible compared to the amount of drawdown in response to pumping events (up to $25 \mathrm{ft}$ ) and, therefore, were ignored.

The simple near-linear declining water-level trend does not extrapolate into the recovery period following the aquifer test. During the recovery period, water levels "naturally" increased above the extrapolated background water-level trend. To prevent overcorrecting the recovering water levels for a diminished or nonexistent declining natural trend, the background trend was smoothly adjusted upward for the time during the pumping events (fig. 6).

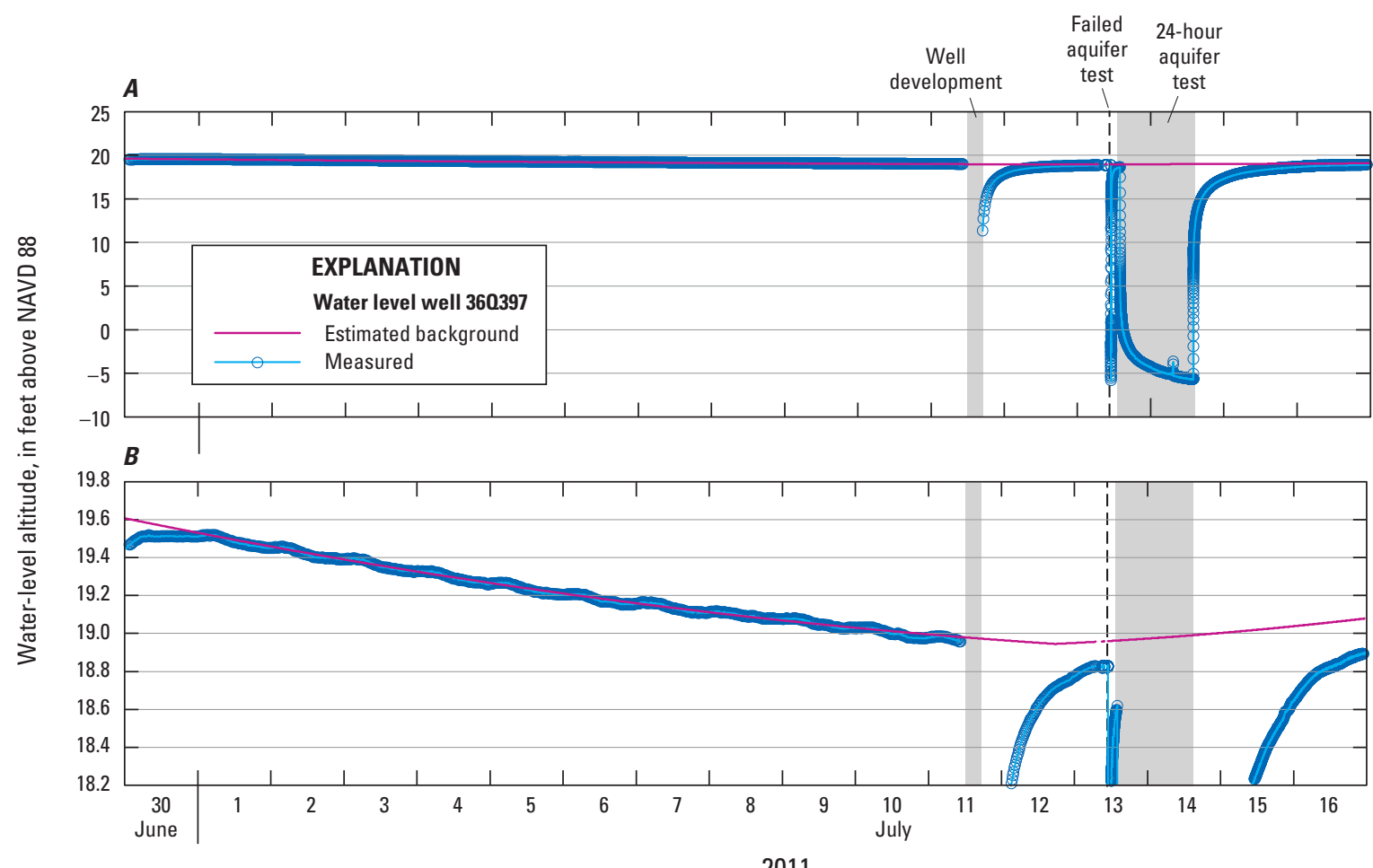

2011

Figure 6. Estimated background and measured water level in ballfield well 360397 at Hunter Army Airfield near Savannah, Georgia, June $30-J u l y ~ 18,2011$. A. General water level. $B$. Vertical close-up of graph $A$ near the estimated background water level. 


\section{Aquifer-Test Analysis}

To account for the multiple pumping events that affected drawdown, water level was simulated using the Theis formula (Theis, 1935) on multiple changes in discharge rate:

$$
D D_{(t)}=\frac{1}{4 \pi T} \sum_{i=1}^{n}\left\{\Delta Q_{i} W\left(\frac{r^{2} S}{4 T\left[t-\tau_{i}\right]}\right)\right\}
$$

where,

$D D_{(t)} \quad$ is the drawdown and residual drawdown in response to multiple changes in discharge rate at time $t$, in feet;

$\left(\frac{r^{2} S}{4 T\left[t-\tau_{i}\right]}\right)$

is the argument " $u$ " in the Theis well function $W(u)$ for the discharge-rate change $i$ at time $t$;

$T$ is the aquifer transmissivity, in feet squared per day;

$S \quad$ is the aquifer storativity or the "storage coefficient," dimensionless;

$n$ is the number of discharge-rate changes;

$\Delta Q_{i} \quad$ is the increase in discharge rate from one step to the next, in cubic feet per day;

$r \quad$ is the effective radius of the pumped well, in feet;

$\tau_{i} \quad$ is the time of discharge-rate step change $i$; and

$\left[t-\tau_{i}\right] \quad$ is the time after the start of discharge-rate step change $i$ at time $t$, in days.

The value of $\Delta Q_{i} W\left(\frac{r^{2} S}{4 T\left[t-\tau_{i}\right]}\right)$ is zero when $t \leq \tau_{i}$.

$\Delta Q_{i}$ is negative when the discharge decreases from one step to the next. Discharge-rate changes that were used to simulate drawdown are listed in table 1.
Table 1. Discharge-rate changes used in the model to simulate the drawdown in well 360397 at Hunter Army Airfield near Savannah, Georgia, July 2011.

\begin{tabular}{ccc}
$\begin{array}{c}\text { Pumping schedule- } \\
\text { Time of start of } \\
\text { discharge rate } \\
\text { YYYY-MM-DD hh:mm:ss }\end{array}$ & $\begin{array}{c}\text { Discharge rate } \\
\text { per day }\end{array}$ & $\begin{array}{c}\text { Gallons } \\
\text { per minute }\end{array}$ \\
\hline 2011-07-01 00:00:00 & 0.00 & 0.0 \\
2011-07-11 10:45:00 & $11,550.00$ & 60.0 \\
2011-07-11 16:50:00 & 0.00 & 0.0 \\
2011-07-13 11:00:05 & $19,442.50$ & 101.0 \\
2011-07-13 11:02:05 & $13,667.50$ & 71.0 \\
2011-07-13 11:08:05 & $11,357.50$ & 59.0 \\
2011-07-13 11:11:05 & $6,160.00$ & 32.0 \\
2011-07-13 11:12:05 & 0.00 & 0.0 \\
2011-07-13 14:00:05 & $9,625.00$ & 50.0 \\
2011-07-14 06:51:05 & $9,413.25$ & 48.9 \\
2011-07-14 06:53:05 & $9,625.00$ & 50.0 \\
2011-07-14 07:24:05 & $8,470.00$ & 44.0 \\
$2011-07-14 ~ 07: 26: 05$ & $9,625.00$ & 50.0 \\
$2011-07-14 ~ 14: 00: 05$ & $8,277.50$ & 43.0 \\
$2011-07-14 ~ 14: 01: 05$ & 0.00 & 0.0 \\
\hline
\end{tabular}


Simulated drawdown closely matched the measured drawdown and residual drawdown using values of hydrologic parameters that are typical for the represented lithology (confined sand). Compared to simulated drawdown (drawdown during the aquifer test), the match between simulated and measured residual drawdown (drawdown during recovery) had a somewhat poorer match (fig. 7). The poorer match during recovery may result from the background water-level trend not being accurately estimated for the recovery period. The best simulation match was obtained using values of transmissivity, storativity (coefficient of storage), and effective well radius of 429 feet squared per day $\left(\mathrm{ft}^{2} / \mathrm{d}\right), 0.0026$, and $0.625 \mathrm{ft}$, respectively. Considering a $19-\mathrm{ft}$ thickness, hydraulic conductivity of the shallow, confined sand unit is estimated to be about 20 feet per day (ft/d), which is consistent with published estimates for fine sand (Freeze and Cherry, 1979). Based on the model fit, the transmissivity of the shallow, confined sand unit in the surficial aquifer system is determined to be about $400 \mathrm{ft}^{2} / \mathrm{d}$ (rounded to one significant digit).

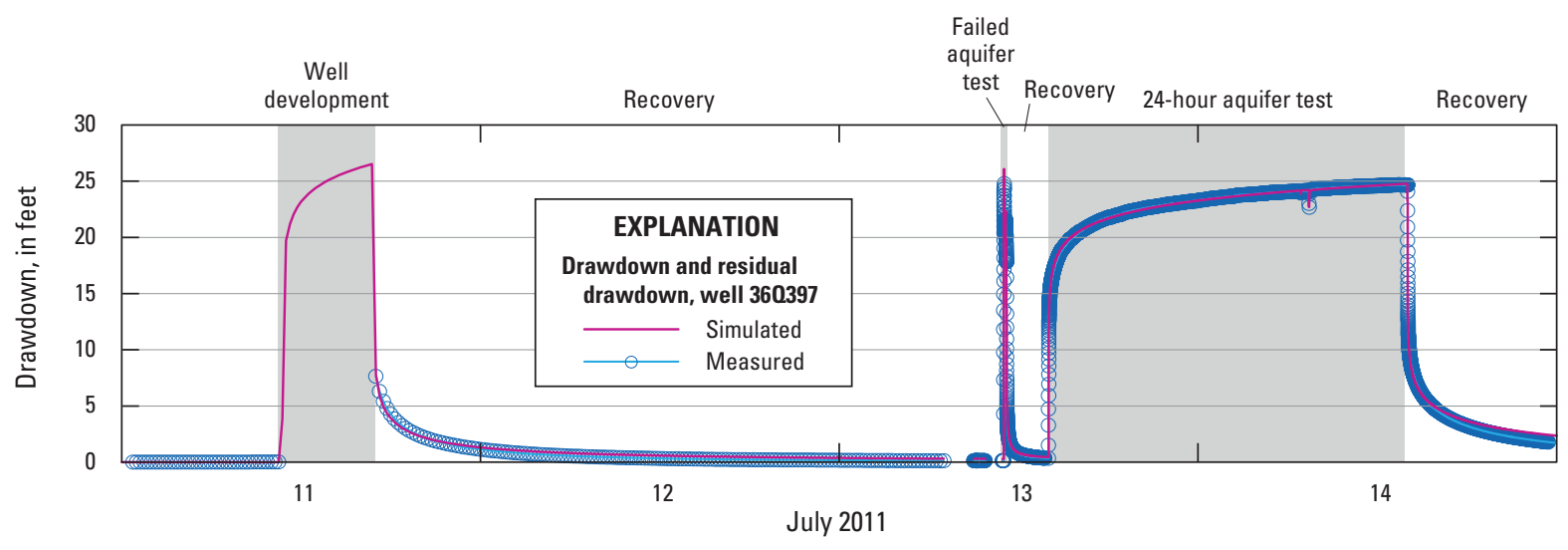

Figure 7. Simulated and measured drawdown and residual drawdown at ballfield well 360397 at Hunter Army Airfield near Savannah, Georgia, in response to three pumping events, July 11-14, 2011. Residual drawdown is the remaining, decreasing drawdown that occurs after pumping when water level is recovering. 


\section{Water Quality}

A water-quality sample collected from well 36Q397 on July 14, 2011, indicated that the water is suitable for irrigation purposes (table 2). Sample analysis indicated a calciumcarbonate type water with a total dissolved solids concentration of 39 milligrams per liter $(\mathrm{mg} / \mathrm{L})$; specific conductance was 90.5 microsiemens per centimeter at 25 degrees Celsius $(\mu \mathrm{S} / \mathrm{cm})$, chloride concentration was $6.05 \mathrm{mg} / \mathrm{L}$, and iron and manganese concentrations were 209 and 17.4 micrograms per liter $(\mu \mathrm{g} / \mathrm{L})$, respectively.

Water quality for the purpose of irrigation is often assessed using specific conductance, which measures the ionic strength of dissolved ions within the water. Plants have to overcome the strength of the ions to water to uptake the water. An increase in specific conductance decreases the water available to plants (Bauder and others, 2011). Generally, there are no detrimental effects to any plants until specific conductance exceeds $750 \mu \mathrm{S} / \mathrm{cm}$. The water sample from well 36Q397 had a much lower specific conductance $(90.5 \mu \mathrm{S} / \mathrm{cm})$ than the level considered harmful.

Other water-quality concerns for irrigation include sodium, a major ion available for chemical reactions (Bauder and others, 2011). An abundance of sodium with respect to calcium and magnesium can lead to excessive soil accumulation of sodium, which can cause swelling of soil clays and cause pore plugging. This condition of poor soil infiltration is known as "sodicity." Sodium ( 0.25 milliequivalents per liter, meq/L) was not the dominant ion in the water sample collected from well 36Q397; instead, calcium ( $0.44 \mathrm{meq} / \mathrm{L})$ and magnesium $(0.10 \mathrm{meq} / \mathrm{L})$ were dominant. Thus, irrigation water from this well is not likely to cause sodicity.

Chloride concentrations below $70 \mathrm{mg} / \mathrm{L}$ are generally safe for all plants (Bauder and others, 2011). This chloride concentration threshold is more than 10 times more than the $6.05 \mathrm{mg} / \mathrm{L}$ measured in the water sample collected from well 36Q397.

Water with dissolved iron and manganese can stain surfaces on contact. Secondary water-quality criteria for iron and manganese, as specified by the U.S. Environmental Protection Agency, are 300 and $50 \mu \mathrm{g} / \mathrm{L}$, respectively (U.S. Environmental Protection Agency, 2011). Both iron $(209 \mu \mathrm{g} / \mathrm{L})$ and manganese $(17.4 \mu \mathrm{g} / \mathrm{L})$ concentrations in the water sample from well 36Q397 are less than the secondary water-quality criteria. No concentration of analyzed constituents from the water sample exceeded the water-quality criteria for human health.
Table 2. Water quality in well 360397 , ballfield complex, Hunter Army Airfield near Savannah, Georgia, July 14, 2011.

$[<$, less than; $\mathrm{mg} / \mathrm{L}$, milligram per liter; S.U., standard $\mathrm{pH}$ unit; $\mu \mathrm{S} / \mathrm{cm}$ at $25^{\circ} \mathrm{C}$, microsiemen per centimeter at 25 degrees Celsius; $\mathrm{CaCO}_{3}$, calcium carbonate; - , none available]

\begin{tabular}{|c|c|c|c|}
\hline Constituent & Concentration & Unit & $\begin{array}{c}\text { Water-quality } \\
\text { criteria }\end{array}$ \\
\hline \multicolumn{4}{|c|}{ Cations } \\
\hline Calcium & 8.82 & $\mathrm{mg} / \mathrm{L}$ & - \\
\hline Iron & 209 & $\mu \mathrm{g} / \mathrm{L}$ & $300^{\mathrm{a}}$ \\
\hline Magnesium & 1.17 & $\mathrm{mg} / \mathrm{L}$ & - \\
\hline Manganese & 17.4 & $\mu \mathrm{g} / \mathrm{L}$ & $50^{\mathrm{a}}$ \\
\hline Potassium & $<1$ & $\mathrm{mg} / \mathrm{L}$ & - \\
\hline Sodium & 5.77 & $\mathrm{mg} / \mathrm{L}$ & - \\
\hline \multicolumn{4}{|c|}{ Anions } \\
\hline Bromide & $<5$ & $\mathrm{mg} / \mathrm{L}$ & - \\
\hline Chloride & 6.05 & $\mathrm{mg} / \mathrm{L}$ & $70^{\mathrm{b}}$ \\
\hline Fluoride & $<1$ & $\mathrm{mg} / \mathrm{L}$ & $1.5^{\mathrm{c}}$ \\
\hline Sulfate & 6.42 & $\mathrm{mg} / \mathrm{L}$ & - \\
\hline Bicarbonate & $31.09^{\mathrm{d}}$ & $\mathrm{mg} / \mathrm{L}$ & - \\
\hline \multicolumn{4}{|c|}{ Other constituents } \\
\hline $\mathrm{pH}$ & 6.96 & S.U. & - \\
\hline Total alkalinity & 25.6 & $\mathrm{mg} / \mathrm{L}$ & - \\
\hline $\begin{array}{l}\text { Bicarbonate } \\
\text { alkalinity as } \\
\mathrm{CaCO}_{3}\end{array}$ & 25.5 & $\mathrm{mg} / \mathrm{L}$ & - \\
\hline $\begin{array}{l}\text { Specific } \\
\text { conductance }\end{array}$ & 90.5 & $\begin{array}{l}\mu \mathrm{S} / \mathrm{cm} \\
\text { at } 25^{\circ} \mathrm{C}\end{array}$ & $750^{\mathrm{b}}$ \\
\hline $\begin{array}{l}\text { Total dissolved } \\
\text { solids }\end{array}$ & 39 & $\mathrm{mg} / \mathrm{L}$ & - \\
\hline
\end{tabular}

${ }^{a}$ Secondary water-quality criteria (U.S. Environmental Protection agency, 2011).

${ }^{b}$ Water-quality criteria for irrigation (Bauder and others, 2011).

'Water-quality criteria for human health (World Health Organization, 1984).

${ }^{\mathrm{d} B i c a r b o n a t e}$ concentration was calculated from bicarbonate alkalinity as $\mathrm{CaCO}_{3}$. 


\section{Summary}

To meet the growing water demand in the 24-county coastal area of Georgia, the Georgia Environmental Protection Division has encouraged usage of alternative sources of water to the Upper Floridan aquifer, including wells completed in the surficial aquifer system. Hunter Army Airfield seeks to use the surficial aquifer system to irrigate a ballfield complex. Drillers' and geophysical logs in a 300-foot-deep test hole indicated a sediment sequence consisting of mostly clay and fine sand above the Upper Floridan aquifer. The surficial aquifer system consists of fine sand at depths of less than 105 feet, with sand layers extending from 11 to 20 feet and 37 to 56 feet below land surface. A well, open to the shallow, confined sand unit at 37 to 56 feet below land surface, was installed to a depth of about 80 feet using an 8-inch-diameter polyvinyl chloride casing and screen.

A single-well aquifer test was conducted to estimate the transmissivity of the shallow, confined sand unit. A 24-hour aquifer test was performed by pumping well 36Q397 at a rate of 50 gallons per minute from 2:00 p.m., July 13th, until 2:00 p.m., July 14th. The water level in the well dropped from about 5 feet below land surface just prior to the aquifer test to about 30 feet in response to the aquifer test, remaining above the top of the shallow, confined sand unit during the aquifer test. Two pumping events prior to the aquifer test resulted in residual drawdown and measurable water-level recovery during the aquifer test. To account for the multiple pumping events that affected drawdown, water-level response was simulated using the Theis formula on multiple changes in discharge rate. Simulated drawdown and residual drawdown matched well with the measured drawdown and residual drawdown using values of hydrologic parameter values that are typical for the represented lithology (confined sand). Based on the best simulation match, the transmissivity of the shallow, confined sand unit in the surficial aquifer system was determined to be about 400 feet squared per day.

A water-quality sample collected from well 36Q397 indicated that the water is suitable for irrigation purposes. The water sample is a calcium-carbonate type with total dissolved solids of 39 milligrams per liter. Water in the sample had a specific conductance of 90.5 microsiemens per centimeter at 25 degrees Celsius and a chloride concentration of 6.05 milligrams per liter. Iron and manganese concentrations in the water sample were 209 and 17.4 micrograms per liter, respectively. The value of specific conductance, relative chemical activity of sodium, and the concentration of chloride were well below the levels that would be a concern for irrigation. Iron and manganese concentrations were less than secondary water-quality criteria concentrations.

\section{References Cited}

Bauder, T.A., Waskom, R.M., Sutherland, P.L., and Davis, J.G., 2011, Irrigation water quality criteria: Colorado State University, Fact Sheet 0.506, 4 p.

Clarke, J.S., 2003, The surficial and Brunswick aquifer systems - Alternative ground-water resources for coastal Georgia, in Hatcher, K.J., ed., Proceedings of the 2003, University of Georgia, Institute of Ecology, Athens, Ga., CD-ROM.

Clarke, J.S., Cherry, G.C., and Gonthier, G.J., 2011, Hydrology and water quality of the Floridan aquifer system and effects of Lower Floridan aquifer pumping on the Upper Floridan aquifer at Fort Stewart, Georgia: U.S. Geological Survey Scientific Investigations Report 2011-5065, 59 p.

Clarke, J.S., Hacke, C.M., and Peck, M.F., 1990, Geology and ground-water resources of the coastal area of Georgia: Georgia Geologic Survey Bulletin 113, 106 p.

Clarke, J.S., and Krause, R.E., 2000, Design revision, and application of ground-water flow models for simulations of selected water-management scenarios in the coastal area of Georgia and adjacent parts of South Carolina and Florida: U.S. Geological Survey Water-Resources Investigation Report 00-4084, 93 p.

Clarke, J.S., Williams, L.J., and Cherry, G.C., 2010, Hydrogeology and water quality of the Floridan aquifer system and effect of Lower Floridan aquifer pumping on the Upper Floridan aquifer at Hunter Army Airfield, Chatham County, Georgia: U.S. Geological Survey Scientific Investigations Report 2010-5080, 56 p.

Cunningham, W.L., and Schalk, C.W., comps., 2011, Groundwater technical procedures of the U.S. Geological Survey: U.S. Geological Survey Techniques and Methods 1-A1, 151 p., available online only at $h t t p: / / p u b s . u s g s . g o v / t m / 1 a 1 /$.

Freeze, R.A. and Cherry, J.A., 1979, Groundwater: New Jersey, Prentice-Hall, 604 p.

Garber, M.S., and Koopman, F.C., 1968, Methods of measuring water levels in deep wells: U.S. Geological Survey Techniques of Water-Resources Investigations, book 8, chap. A1, $23 \mathrm{p}$.

Halford, K.J., 2006, Documentation of a spreadsheet for timeseries analysis and drawdown estimation: U.S. Geological Survey Scientific Investigation Report 2006-5024, 38 p. 
Huddlestun, P.F., 1988, A revision of the lithostratigraphic units of the Coastal Plain of Georgia-The Miocene through Holocene: Georgia Geological Survey, Bulletin 104, 162 p.

Miller, J.A., 1986, Hydrogeologic framework of the Floridan aquifer system in Florida and in parts of Georgia, Alabama, and South Carolina: U.S. Geological Survey Professional Paper 1403-B, 33 plates, $91 \mathrm{p}$.

Randolph, R.B., Pernik, Maribeth, and Garza, Reggina, 1991, Water-supply potential of the Floridan aquifer system in the coastal area of Georgia-A digital model approach: Georgia Geologic Survey Bulletin 116, 30 p.

Stallman, R.W., 1971, Aquifer-test design, observation, and data analysis: U.S. Geological Survey Techniques of WaterResources Investigations, book 3, chap. B1, 26 p.

Theis, C.V., 1935, The relation between the lowering of the piezometric surface and the rate and duration of discharge of a well using groundwater storage: American Geophysical Union Transactions, v. 16, p. 519-524.

U.S. Environmental Protection Agency, 2011, Drinking water contaminants: Accessed October 24, 2011, at $h t t p: / / w w w$. epa.gov/safewater/contaminants/index.html\#listmcl.

Weems, R.E., and Edwards, L.E., 2001, Geology of Oligocene, Miocene, and younger deposits in the coastal area of Georgia: Georgia Geologic Survey Bulletin 131, 124 p.

World Health Organization, 1984, Guidelines for drinkingwater quality, volume 2 , health criteria and other supporting information ( $2 \mathrm{~d}$ ed): Geneva, World Health Organization, variously paginated.

Manuscript approved on April 24, 2012

Edited by Michael Deacon

Layout by Caryl J. Wipperfurth

Science Publishing Network, Raleigh PSC

For more information about this publication, contact: USGS Georgia Water Science Center 3039 Amwiler Road

Atlanta, GA 30360

telephone: 770-903-9100

http://ga.water.usgs.gov/ 
올

言 